\title{
Pacific Islands Trade, Labor, and Security in an Era of Globalization
}

Stewart Firth

\begin{abstract}
G I him Li Garments closed their factories in Nadi, Ba, and Lautoka, Fiji, in April 2005, throwing more than three thousand employees out of work and indirectly hurting business for bus companies, food-stall owners, and taxi drivers. Thousands more garment workers were expected to lose their jobs in 2006 following Fiji's apparent failure to renegotiate the terms of the South Pacific Trade and Economic Agreement with Australia and New Zealand (SPARTECA) (PIR 2006c). In April 2006 insurgents attacked a supply convoy headed for the US airbase in Kirkuk, Iraq, killing four Fijians: Kelemedi Dreuvakabalawa of Nauluvatu Village, Nakelo; Malakai Sekibureta of Naimasimasi Village, Tailevu; Iosefo Cagi of Vatulili, Naitasiri; and Anasa Navukaro of Navuniivi, Ra (PIR 2006b). They were four of more than a thousand Fijians in Iraq's privatized security industry, working for companies contracted mainly by the US military. In the same month hundreds of young men gathered at the parliament building in Honiara, capital of Solomon Islands, to see who would become prime minister. When they realized it was Snyder Rini, a politician renowned for corruption, they hurled abuse, threw stones, torched a police vehicle, and, in the hours that followed, rampaged through Honiara in a riot that left Chinatown mostly destroyed.

These events, unconnected to each other, are related directly or indirectly to the phenomenon we call globalization, and the areas of economic and political life they exemplify - trade, labor, and security-are where globalization is having its most transformative effects in the Pacific. These areas are the subjects of this article.

Globalization, David Held has argued, "refers to a shift or transformation in the scale of human organization that links distant communities
\end{abstract}


and expands the reach of power relations across the world's regions. This shift can be mapped by examining the expanding scale, growing magnitude, speeding up and deepening impact of transcontinental flows and patterns of social interaction" $(2004, \mathrm{I})$. Here I concentrate on the economic dimensions of this shift. Globalization in this narrower, economic sense is characterized by intensified transactions across national borders and is made possible by governments adopting the neoliberal policies in vogue for the last quarter century. The economic advisers and consultants who are so thick on the ground in the Pacific Islands preach this neoliberal policy message. They come from foreign governments, aid agencies, international financial institutions, regional organizations, and some nongovernmental organizations. Pacific Island governments, having little alternative, endorse what they recommend.

We should remember that economics, while it claims authority on the basis of technical expertise, is in fact a branch of political philosophy favoring one political outcome over another. The technical recommendation of neoliberal economics, for example, is to give freer rein to market forces in economic life, to privatize public enterprises, to float currencies, to replace protection with free trade, and to reduce the freedoms enjoyed by organized labor while enlarging the freedoms of capital. As became clear after the World Trade Organization (wTO) was formed in I995, globalization is also a project aimed at extending property rights over new areas such as ideas, inventions, and biological life. Once we translate technical into political, we find that neoliberal economists are saying that corporate power should be enhanced and that wealth and income should be distributed more unequally because this is the only route to rapid economic growth. A more unequal distribution of incomes has certainly emerged in the last twenty-five years in the United States, where "the share of aggregate income going to the highest-earning I \% of Americans has doubled from $8 \%$ in 1980 to over $16 \%$ in 2004 . That going to the top tenth of $\mathrm{I} \%$ has tripled from $2 \%$ in 1980 to $7 \%$ today" (Economist 2006). Neoliberal economic globalization, in other words, is not taking place in a political vacuum but in circumstances shaped by culture and history, and in particular by the contemporary predominance in global affairs of the United States.

This observation applies to the impact of globalization on the Pacific Islands. The culture, history, politics, and demography of the Pacific Islands cannot be ignored in the debate about globalization, because they are shaping its forms and effects in this part of the world. 


\section{Trade and Regional Economic Integration}

The global move from protection to free trade has reached the Pacific Islands. (For a critical analysis, see Kelsey 2004 and Kelsey 2005.) Leaders of the Forum Island States (that is, the I4 Pacific Island countries in the Forum, excluding the 2 others, Australia and New Zealand) committed themselves in 1999 to negotiating a regional free-trade area and eventually reached a Pacific Island Countries Trade Agreement (PICTA), which came into effect in 2003 . The geographical scope of this agreement is the Island Pacific; it covers trade only in goods, not services; and it provides that the 5 developing Forum Island countries will remove all tariffs and restrictions by 2010 , while the 9 small island states and least developed countries will do so by $20 \mathrm{I} 2$. With detailed provisions about rules of origin, most-favored-nation treatment, trade distorting measures, and even dumping, PICTA appears to be a significant regional extension of global free trade. Yet, like many poor countries, the Forum Island states sell little to each other. The agreement covers a tiny percentage of their trade, which is mostly with the rest of the world, especially with Australia and New Zealand. PICTA will not change much in the way Island economies work, except perhaps to concentrate breweries and tobacco manufacture in a few countries.

Why, then, have the Island countries bothered to negotiate free trade among themselves? The answer is that Island countries are seeking to reassure aid donors and the institutions of global governance that they are adapting to the new global trading order. The plan for a free-trade area signaled the region's willingness to consider new measures for dealing with globalization and trade liberalization through regional integration. In any case, PICTA is merely a stepping-stone to comprehensive freetrade initiatives that will have a far greater impact on the economic prospects of the Island countries and the working lives of their people.

The first of these initiatives concerns the region's two largest trading partners, Australia and New Zealand, and is called the Pacific Agreement on Closer Economic Relations (PACER). Whereas PICTA mandates free trade only among the Island countries of the Forum, PACER, in effect since 2002, provides for the eventual extension of the regional free-trade area to Australia and New Zealand. Under PACER provisions, Forum Island countries must enter into free-trade and economic integration negotiations with Australia and New Zealand no later than eight years after PICTA 
entered into force, that is, by $20 \mathrm{I}$, and in any case when the Island states begin negotiating over free trade with any country or group of countries that have a higher per capita income than New Zealand. This last provision for a trigger is designed to ensure that Australia and New Zealand are not disadvantaged by the Islands' trade arrangements with the European Union (EU), since these are also changing and are headed firmly in the direction of free trade. The Island countries began free-trade talks with the European Union in 2004 , a process that is expected to lead to PACER talks with Australia and New Zealand in a few years' time.

The PACER goal is to "establish a framework for the gradual trade and economic integration of the economies of the Forum members in a way that is fully supportive of sustainable development of the Forum Island Countries and to contribute to their gradual and progressive integration into the international economy" by developing a single regional market (Australian Parliament 2002, para 8). The phrase "Forum members" is important, because it includes Australia and New Zealand, which under PACER terms will seek to integrate the Island economies with their own in a comprehensively liberalized trade and investment regime. While the process will be gradual, the end effect will be that PACER will overtake PICTA and incorporate Island countries into a free-trade area dominated by Australia and New Zealand.

The second free-trade initiative now being negotiated in the Pacific Islands is with the European Union. The impetus for the European Union to change its aid and trade relationship with the Pacific Islands came when the Uruguay Round of the General Agreement on Tariffs and Trade concluded in I994 and the World Trade Organization was established soon afterward. The Uruguay Round expanded the definition of what "trade" was, by covering a wide range of trade in services, and at the same time extended copyright protection internationally into new areas such as intellectual property. The World Trade Organization, which has the task of administering and enforcing the growing body of multilateral trade agreements, is a key institution of globalization and free trade. The outcome, according to the European Union, was "a new multilateral context which is speeding up a globalization of the economy driven by technological change and the liberalization of economic policies that started in the 1980s" (EC 1996, i).

The "new multilateral context" of globalization and liberalization compelled a fundamental reconsideration by the European Union of its relations with the countries of the Africa, Caribbean, and Pacific Group 
(ACP). The time had come for "breathing fresh life into the ACP-EU partnership and recharging it with the relevance and effectiveness needed to face up to the challenges of the 2ist century," according to the experts in Brussels, and in a I996 EU Green Paper they declared where they wanted the partnership to go (EC I996). The destination was globalization, and the European Union's role was now to assist developing countries to integrate into the global economy. The state in developing countries was no longer to undertake development itself, but rather to create the conditions for profitable private enterprise, as the economy moved from being regulated and protected to being open to international pressures. The EU vision of a successful economy was firmly neoliberal: "Macroeconomic stability, realistic and stable exchange rates, good institutions and good governance, and efficient resource allocation policies, in particular stable and credible import and taxation regimes, as well as reduced trade protection, which allow a transparent transmission of world price signals to domestic producers, are significant determinants of competitiveness and hence of export performance. These supply-side factors are now considered much more important than trade preferences in achieving high rates of export and economic growth" (EC I996, I7-I 8). Aid would become more conditional, and the key condition would be good governance in aid-recipient states. Free trade would replace preferential trade, and the European Union would negotiate free-trade agreements separately with different parts of the developing world.

The consequences of this shift in EU policy continue to reverberate throughout the developing world, not least in the ACP countries, which, from the I970s, came under the provisions of successive versions of the Lomé Convention. The Africa, Caribbean, and Pacific Group dates from 1975, when a group of 46 former European colonies negotiated a special trade and aid relationship with the European Community, then recently enlarged by the addition of the United Kingdom. By 2006 ACP membership had expanded to 79, including East Timor, and the total population to more than 740 million people, mostly in Africa. The original 8 Pacific member states were Fiji, Kiribati, Papua New Guinea, Sāmoa, Solomon Islands, Tonga, Tuvalu, and Vanuatu-all former colonial territories of Britain, France, or Germany, at one time or another-and a further 6 joined in 2000: Cook Islands, Nauru, Niue, the Marshall Islands, the Federated States of Micronesia, and Palau.

By far the most important Lomé trade arrangement in the Pacific was the Sugar Protocol, which gave Fiji sugar preferential access to Europe at 
a generous price. The Sugar Protocol was annexed to the Lomé Convention in the mid-I970s, at a time when there was a shortage of sugar worldwide and commodity-exporting developing countries were briefly in a strong bargaining position. The protocol provides for I9 ACP countries (Barbados, Belize, Congo, Côte d'Ivoire, Fiji, Guyana, Jamaica, Kenya, Madagascar, Malawi, Mauritius, St Kitts and Nevis, Suriname, Swaziland, Tanzania, Trinidad and Tobago, Uganda, Zambia, and Zimbabwe) to supply the European Community with agreed quantities of cane sugar at guaranteed prices. Each of these countries holds quotas, and Fiji is among the 5 largest quota-holders. The EU Council decides annually what the guaranteed prices for raw sugar and white sugar will be. In effect, the Sugar Protocol with ACP countries gives developing countries in the Caribbean, Africa, the Indian Ocean, and the Pacific a price for sugar that matches the one paid to domestic producers within Europe, and in this way it is linked to the European Union's own, internal sugar regime, which dates from 1968 and is part of the Common Agricultural Policy. At a cost now running at $\mathrm{I} .2 \mathrm{I} 7$ billion euros a year, the EU sugar regime guarantees prices for sugar grown within the 2I sugar-growing countries of the EU-25 (all of the expanded European Union except for Luxembourg, Estonia, Cyprus, and Malta), of which the most important are France and Germany. Europe, as a result, is a major sugar producer (Gillson, Hewitt, and Page 2005).

The Sugar Protocol, unlike the rest of Lomé, originated as a permanent arrangement, not one that was subject to regular review, and in theory it could continue indefinitely. The protocol's terms were not changed when Cotonou replaced Lomé, though technically it was now a Cotonou protocol. Those terms, however, allowed either side of the arrangement-the European Union or the ACP Protocol countries- to withdraw with two years' notice, and the European Union is now in the process of bringing the Protocol to an end. The pressure on the European Union to change comes from the global move to free trade led by the World Trade Organization and from the long-standing criticism that European agriculture survives on the massive subsidies of the Common Agricultural Policy. Some countries object in particular to EU export subsidies on sugar, and Australia joined Brazil and Thailand in challenging these subsidies at the World Trade Organization, claiming they were in breach of the European Union's wто obligations. The World Trade Organization agreed, and ruled against the European Union in 2004. Since the Sugar Protocol is, in essence, an overseas extension of the EU internal sugar regime, changes to 
that regime threaten the Protocol, and the ACP Protocol countries now confront globalization in the form of free trade in sugar.

The implications of this change are profound for Fiji, where thousands of small farmers depend on a sugar industry that survives largely on European price support. The structure of the Fiji sugar industry dates from the I920s, when the Colonial Sugar Refining Company moved sugar growing from plantations to smallholdings of ten acres each. Plantation laborers, mostly of Indian descent, became small farmers, tied to the company by agreements that dictated how much they would grow and what the price would be. And when Colonial Sugar sold out to the Fiji government in I973, the state-owned Fiji Sugar Corporation inherited the same smallholding production system, complete with aging mills, machinery, railways, rail stock, and other infrastructure. The four sugar mills owned by the Fiji Sugar Corporation-at Rakiraki, Ba, Lautoka, and Labasa-all date from the nineteenth century, and have mostly made losses since 1997. More than that, the Fiji Sugar Corporation inherited an industry highly resistant to change.

Fiji without sugar seems inconceivable. People see sugar as the foundation of the country's wealth, and there is a "widespread belief throughout the industry that the sugar industry will not be allowed to fail because the stakes are too high" (Reddy 2003, 27I). The government has fostered this belief by lending money to the Fiji Sugar Corporation and then, when it cannot repay, converting the loans into grants. Fiji sugar production has declined in recent years, but the industry still employs more than 20,000 people in cultivation with another 24,000 involved in cane cutting, transport, and milling. Fiji, together with Guyana, Mauritius, Swaziland, and Belize, stands to lose most among ACP countries from the end of preferential access to the EU sugar market, both in absolute terms and in proportion to gross domestic product (GDP) and export income (Gillson, Hewitt, and Page 2005, 54). As accountancy expert Michael White has soberly concluded, "it is by no means certain that Fiji's sugar industry will be financially viable if it no longer enjoys preferential access to certain markets, even if it is able to successfully restructure. . . . The most appropriate policy to pursue may well be one that enables the orderly winding down of the industry and its ultimate closure" (White 2003, 299).

The question might well be asked: Why did Fiji not restructure the sugar industry earlier? The writing, after all, has been on the wall for a decade, and a succession of observers, advisers, and EU representatives has been pointing to the urgent need for reform for years. The answer lies 
partly in politics and partly in the Fiji bureaucracy. The sugar industry in Fiji is highly politicized, and in a way that has blocked reform. Sugar sustains a whole way of life in western Viti Levu and parts of Vanua Levuthe only way of life many farmers can imagine-and defending the interests of the farmers has become a key political resource for Indo-Fijian politicians, not least for the former Labor Party prime minister overthrown in 2000, Mahendra Chaudhry. On the other hand, Fijian politicians such as Prime Minister Laisenia Qarase have posed as defenders of the rights of the Fijian landowners from whom the land is leased at a time when land leases dating from the I970s have been expiring. While both sides have done battle over sugar, neither has focused on the more fundamental issue of whether it has a future. The Speight coup of 2000 exacerbated these tensions between the country's two major communities and diverted people's attention from what needed to be done for the nation as a whole. The major restructuring of an economy would tax the energies of any government-and most of all, those of the government of an Island nation such as Fiji, which is too small to possess the depth of bureaucratic expertise to sustain a project of this kind. There are highly talented individuals in the Fiji bureaucracy with an impressive command of these issues-one thinks of Isikeli Mataitoga, CEO of Fiji's Ministry of Foreign Affairs and External Trade, for example-but there are not enough of them.

The coming demise of the Sugar Protocol, then, will transform the Fiji economy over the coming decade. The change is beginning. The European Union is cutting the import price for preferential raw sugar imports by at least 37 percent over three years from I July 2005 and will reduce quotas as well. In all likelihood, the special import price will disappear altogether sometime after 2008 , and the Fiji sugar industry will have to sink or swim at the much lower world price.

The European Union is considering transitional assistance for countries affected by free trade, and is likely to assist restructuring rather than pay compensation to farmers. As a 2005 British report points out, this "could include measures to increase the competitiveness of the declining sector (including branding and niche marketing opportunities) or developing and marketing related products e.g. ethanol from sugar. Niche markets (such as Fair Trade or organics) provide a price premium which could allow some ACP Protocol countries to maintain production." However, the report warns, "these approaches may be unable to preserve significant levels of output for those countries whose long-term competitiveness is in 
decline. In the long run, diversification into other activities is the best strategy for high cost ACP Protocol countries" (Gillson, Hewitt, and Page $2005,5)$. Given that Fiji's competitiveness as a sugar producer has been declining in recent years, the corollary is that the sugar industry can survive there only in radically restructured form, if at all.

The Fiji sugar industry will probably decline slowly rather than collapse overnight. It will not end abruptly, as happened in 2005 on the Caribbean island of St Kitts. The Fiji sugar mills are being modernized and re-equipped according to the recommendations of a technical mission sent by the government of India, and sugar will survive temporarily on lifelines of this kind. The Eu transitional package will temporarily soften the blow of lower sugar prices. The Fiji government will be under intense political pressure not to let sugar fail and, as in the past, it will prop up the Fiji Sugar Corporation. Efforts will be made to diversify into products such as ethanol, and farmers will win temporary reprieves from failure when the world sugar price rises, as it did in 2006. A permanently higher world price - the only development that could actually rescue Fiji sugar-should, in theory, follow from abolishing subsidies and preferential arrangements, but even if that happens, the global sugar market is likely to remain distorted. The European Union is contesting the wTO ruling against export subsidies on sugar, for example, ensuring the subsidies continue for some years; and, even though sugar will be reformed within Europe, the European Union will not impose neoliberal solutions on itself with the enthusiasm it has imposed them on others. For Fiji, the future threatens a dislocation of the sugar industry that is likely to exacerbate urbanization, as farmers who fail to find alternative crops move as squatters to the Suva-Nausori corridor and place further strain on urban infrastructure. An estimated 90,000 people are now living in squatter settlements in the Suva-Nausori corridor, with many more likely to come. One observer suggests, "Fiji may only be at the edge of a significant and potentially chaotic urban demographic explosion for which it is barely prepared" (Storey 2006, 20).

Fiji is also experiencing the end of another wTO-incompatible trade regime originating in the I970s, the Multi Fibre Arrangement (MFA), which expired at the beginning of 2005. The expiry of this arrangement, under which Fiji exported garments to the United States, affected only a few companies, but it has nevertheless delivered a blow to an industry that earns more for Fiji than sugar and employs about I 4,000 people, many of them women whose cash income is a major part of family earnings. As 
we have seen, Ghim Li Garments was especially affected by the end of the Multi Fibre Arrangement and closed in 2005 with the loss of 3,000 jobs. Between 2004 and 2005 the output of Fiji's garment and footwear industries fell by 55 percent (PIR 2006a). The loss of these exports, a direct consequence of globalization, has contributed substantially to halving Fiji's growth rate from more than 4 percent in 2004 to a predicted 2 percent in 2006 (Reserve Bank of Fiji 2005). The Fiji garment industry now relies even more than before on the weakening reed of SPARTECA, recently renewed for another seven years. SPARTECA allows duty-free entry into Australia and New Zealand of certain manufactured goods from the Forum Island Countries, including garments from Fiji, but the Pacific's margin of advantage is declining as Australia and New Zealand reduce their tariffs on garments and other goods from the rest of the world. As further job losses in the garment industry loomed in 2006, Fiji Foreign Minister Kaliopate Tavola complained that tens of thousands of people in Fiji had become "victims of the lack of morals and equity in global economic development" (PIR 2006c). The future for the Fiji garment industry will lie in developing niche markets where there is less competition from China.

To put these developments in perspective, we should note that globalization is also creating opportunities for Fiji, above all in an expanding tourist industry, in services such as call centers, and in a sudden growth in labor migration. Fiji has the region's most diversified economy, and the 2006 elections gave promise of political stability, so the country may emerge stronger from restructuring in the long term. My contention here is simply that globalization has forced a restructuring that, at least in the short term, is likely to have negative social effects.

For Pacific Islanders in general, an important effect of the coming of free trade will be higher indirect taxes. Tariffs are an important source of government revenue for all Pacific Island countries, and their loss will compel governments to seek revenue elsewhere in indirect taxes, especially by increasing the rate at which they are levied. Some countries that currently do not have a value-added tax are contemplating introducing one in order to compensate for the loss of income from tariffs.

At the same time Australia and New Zealand have encouraged the Pacific Islands Forum to embark upon a long-term strategy of regional economic integration under what is called the "Pacific Plan" in order to enhance regional security and make the region competitive in a globalizing age (www.pacificplan.org). The Pacific Islands Forum endorsed the 
Pacific Plan in 2005, and is now committed to regional integration by 20I 5. As a concept, the plan at first seemed pathbreaking. Pacific leaders did not mince words, pointing out that poor governance had produced "instability, violence, corruption and a breakdown of the democratic process," leading to slow economic growth and in some countries economic decline, and that globalization was a major challenge to which the plan would respond. There was talk of "regional integration deeper than that already established under current trade arrangements," of sharing the resources of governance, and of engaging in new thinking about "the relationships between sovereign states" (EPG 2004). Reading between the lines, some observers thought the Pacific Plan might eventually lead to a common Forum area currency and monetary authority like the euro and the European Central Bank.

To date, the Pacific Plan adopted by the Forum falls far short of such transformation. The focus instead is on minor initiatives that constitute only a first step toward regional integration. Crucially, these initiatives must meet the "sovereignty test," placing strict limits on regional policy making. The plan charts a careful course around the shoals of Pacific Islands sovereignty, and is characteristically a Forum document both in devotion to what is desirable-more trade and investment, better governance, sustainable development, participatory democracy, greater security, a halt to the spread of HIV/AIDs and so on-and caution in real commitments. There is much to commend in the aims of the Pacific Plan, and some things will happen-better police training, for example, and an agreement on the temporary migration of labor from one Island state to another-but initial changes will be small-scale. Still, the Pacific Plan is a ten-year process as well as an immediate set of commitments, and more thoroughgoing movement toward regional economic integration might yet come. By 2008 the Forum plans to have integrated trade in services, "including temporary movement of labour," into the Pacific Island Countries Trade Agreement, and into the Economic Partnership Agreement with the European Union (PIF 2005 b, para I 3 ). The Forum also plans to investigate the impact on Island countries of a comprehensive agreement on trade and services with Australia and New Zealand under the Pacific Agreement on Closer Economic Relations. "As successful regionalism requires larger markets to stimulate growth," the plan explains, "partnership with Australia and New Zealand is crucial for Pacific regionalism to be viable" (PIF 2005 b, para I6). The new vision of Pacific Islands regionalism, then, is one that creates a Pacific Islands common market 
and economic community embracing all Forum states including Australia and New Zealand. Given the economic and political dominance of Australia and New Zealand in the Forum region, their inclusion in this vision suggests a future regionalism even more firmly directed by governments in Canberra and Wellington than it is now.

\section{LABOR MigRATION}

The relationship between globalization and labor migration is complicated. Widening global inequalities make people in poor countries desperate for jobs in rich ones, as can be seen from the endless stream of Latin Americans trying to enter the United States across its southern border, the desperate attempts by Africans to reach Europe from Morocco or Libya, and the huge number of Filipinos working overseas. In a truly globalized world economy-one that matched the rhetoric of the globalizers-labor would cross national borders as easily as capital, as happened before World War I in the case of European migration to the United States. In reality, migration is a politically sensitive issue throughout the rich world, and the governments of the Organisation for Economic Co-operation and Development (OECD) countries regulate it in the most exacting and stringent ways, in sharp contradiction to official rhetoric claiming that globalization is about deregulation. Such is particularly the case in Australia, which places all illegal immigrants, including asylum seekers, in detention centers where they may remain for years until their cases are heard.

The impact of globalization on Pacific Islands labor migration needs to be seen in this political context. For years Pacific Islanders have migrated from the Island states and territories to Australia, New Zealand, Canada, and the United States. Wherever people have had automatic right to entry to a metropolitan state (as do Micronesians to the United States or Cook Islanders and Niueans to New Zealand), they have left their home countries in droves, giving lie to the idea that life in the Islands is idyllic. Elsewhere, people also leave if they can. For the last fifteen years the leading remittance economies in the region have been Sāmoa and Tonga, where roughly half the population lives abroad. Many Samoans and Tongans have migrated to New Zealand, which now has a sizable Pacific Islander population, and their remittances have become a vital contribution to national income. In the last four years Fiji has joined Tonga and Sāmoa as a remittance economy, as thousands of Fijians have joined the British Army or been recruited as private security guards. Since the beginning of the war on Iraq, companies such as Global Risk Strategies, Homeland 
Security Limited, Triple Canopy, and Sabre International Security Fiji have sent hundreds of former soldiers and police to Iraq to serve as escorts and guards (Maclellan 2006). Many more are being recruited by other security companies and some have been killed in the line of duty. As Fiji's Reserve Bank Governor points out:

Personal remittances have become a prominent source of foreign exchange for Fiji. Personal remittances have surged to $\$ 300$ million in 2004, compared to a mere $\$ 50$ million five years ago. Remittances are now equivalent to 7 percent of GDP and that is more than many of our traditional economic sectors. They have also displaced garments and sugar on their rise to become the second largest source of foreign exchange earnings for Fiji. Furthermore, we are only capturing remittances that flow through the financial system. There are others that are carried in person and sent through the ordinary mail. There are also those remittances in kind. One estimate puts these unrecorded remittances at over \$ 50 million lifting total remittances above retained tourist receipts. These remittances have come at an opportune time for us, with our exports not performing well. They have given us much-needed breathing space. Everyone should say thank you to all our peacekeepers, security personnel, nurses, sportspersons and family members abroad for helping us pay for our imports. (Narube 2005)

The hunger for cash incomes among Fijians could be seen in Suva as word spread of opportunities in Iraq in 2004, and queues of prospective guards gathered in hundreds at the recruiting headquarters of the security companies in Suva. In this case the driving force behind the exodus of Fijians has been another phenomenon of the globalizing era, the privatization of security and the outsourcing of military support tasks by the US Armed Forces in Iraq.

There is another kind of emigration from Fiji, the permanent departure of people of Indian descent, most of whom are highly skilled and well educated. It can be called "ethnic emigration" and is driven in part by the pull of job opportunities in globalizing economies nearby, and in part by the push of political instability. For years after independence in 1970 a steady flow of skilled and educated Indo-Fijians left their home country in search of a better life overseas. The military coups of 1987 , executed in the name of keeping Fiji for the indigenous Fijians, led to a much greater outflow of people, and the attempted coup by George Speight in 2000 left no Indo-Fijians in doubt that their future in the country of their birth is precarious. That is why more than I००,००० people have left Fiji permanently since 1987 , and why 90 percent of them are Indo-Fijians (Mohanty 2005). ${ }^{1}$ They are now industrious Australians, New Zealanders, Ameri- 
cans, and Canadians, contributing their skills to successful OECD economies and returning to Fiji only as tourists.

Yet labor migration is by no means universal in the Pacific. Only small numbers migrate to the rich world from its most heavily populated subregion-Papua New Guinea, Solomon Islands, and Vanuatu. Fewer people in these countries than in Fiji, Sāmoa, or Tonga possess the education or skills to qualify for entry into the English-speaking countries of the Pacific Rim, or, for that matter, the military training that would fit them for employment in the privatized security industry.

The logic of globalization suggests that Australia and New Zealand should offer easier access to unskilled Pacific Islanders, as seasonal workers even if not as permanent migrants. An Australian Senate committee has recommended a seasonal worker scheme for Pacific Islanders, who would enter Australia on short-term visas to pick fruit and undertake other agricultural work, as many already do illegally (Australian Senate 2003). After all, if free trade is going to allow goods, services, and capital from Australia and New Zealand into the Islands unhindered, why not allow unskilled Pacific Islanders temporary entry to the labor markets of those countries? That is the argument now being advanced by Pacific Islands leaders keen to find employment for their populations, and by the World Bank, which describes the climate as "right to offer consideration of the merits of some form of labor market integration" of Pacific Islands countries with their "Pacific neighbors" (World Bank 2005, I8). The Pacific Islands Forum is saying the same thing, resolving to "continue to consider the issue of labor mobility in the context of member countries' immigration policies" (PIF 2005a). But the atmosphere of domestic politics in Australia runs counter to this proposal. By depicting itself as shielding citizens from the hordes who wish to enter their homeland the Howard government has exploited popular fears of illegal immigration and won votes, and by overturning a century's tradition of protective labor law and high minimum wages it has aroused trade union suspicions of foreign workers. The Howard government has therefore rejected the seasonal Pacific Islander worker idea.

\section{Regional Security}

Globalization and regional security in the Pacific Islands might at first be regarded as distinct from each other, one driven by global economic and technological changes, the other arising from the local political circum- 
stances of Island states. Yet, in at least one case, globalization has proved politically destabilizing and a threat to regional security-or, to put it more accurately, globalization has been a significant element among others in producing political destabilization. As Australia Foreign Minister Alexander Downer has said, "the spread of economic globalization brings great potential benefits-but only if countries can develop strong and resilient institutions, and maintain prudent economic policies. These are preoccupations of developed and developing countries alike. But for developing countries, the risks are particularly high. Hard-won economic gains can be quickly lost by the failure of institutions of governance, and the spread of violence and corruption. The Pacific has already produced one stark example of this-Solomon Islands-and it is important that we produce no more" (2004).

Globalization in Solomon Islands has taken the form of unregulated investment in tropical logging, the country's principal export industry. In one sense this exploitation of natural resources for the global market was globalization in the old sense, familiar in the Pacific since the nineteenth century, but in another it was new, because the rate of exploitation dwarfed anything the country had seen before as loggers moved from Southeast Asia into the virgin forests of the Pacific. An insatiable overseas market for rain-forest timber drove investment at a frenzied and unsustainable rate. In the two decades after independence from Britain in 1978 , the export of round logs by Asian timber companies not only boomed at an ecologically unsustainable level, but also corrupted numerous political leaders who allied themselves with foreign investors. In effect, the logging companies bought whole governments, then systematically underreported exports, while their friends in high office legislated generous tax remissions. The result was a fall in Solomon Islands government revenue and a crisis in the national budget in the mid-I990s, leading to a structural reform program backed by the International Monetary Fund, the Asian Development Bank, and the World Bank. Under structural reform, a new government dismissed hundreds of public servants and cut services, restoring the budget balance while undermining political stability.

Against this background of diminishing government effectiveness, internal migration was creating the conditions for disorder, as thousands of people from Malaita, the Solomons' most populous island, migrated to Guadalcanal in search of the opportunities available in the seat of government at Honiara. Over a period of decades, the newcomers became competitors with the locals for the land, resources, and jobs of Guadal- 
canal, and growing numbers of jobless young men formed an army of ready recruits for anyone ready to give them a purpose. In I998 Guadalcanal militants embarked on a campaign of murder and arson to force the Malaitans off their land, and in the following year the government declared a state of emergency and repatriated thousands of Malaitans to their home island. Tenuous ceasefires reached in I 999 held temporarily, but fundamental problems remained unresolved.

The situation worsened in 2000, when the Malaitans formed their own militia called the Malaita Eagle Force and overthrew the constitutionally elected government, replacing the prime minister with one of their own choosing. Fighting intensified in mid-2000, militants looted much of the capital, and investors closed the country's only gold mine. The economy contracted by an estimated 25 percent in two years, and although a peace agreement between the factions was reached in October 2000, peace proved elusive. The police force now consisted mainly of Malaitans, used its weapons to extort payments from government, and worked hand in hand with those who were undermining the rule of law. Solomon Islands was becoming a failed state (Dinnen 2002; Fraenkel 2004; Moore 2005).

At this point Australia reversed its long-standing policy of avoiding direct intervention in the affairs of Island countries, and sent I, 600 soldiers and police to lead a regional intervention force. The Australian government described it as a "fundamental policy shift by Australia" that "has sharpened the focus of engagement through necessity following the deterioration of security in Solomon Islands and in the context of global security and the understanding that a porous and undeveloped region is not in the interests of Australia" (AusAID 2004a, 4). For the moment, the Regional Assistance Mission to Solomon Islands, while technically operating in support of the sovereign government in Honiara, has in effect established a protectorate administration designed to rebuild the state in that country. The limitations of such intervention became starkly apparent, however, in the Honiara riots of April 2006, and the subsequent dispatch of Australian troops. Snyder Rini was forced to step down in favor of former Prime Minister Manasseh Sogavare, but no one believes the country therefore has a corruption-free future. Key decisions about Solomon Islands will continue to be made in Canberra, where bureaucrats and politicians direct the spending of almost a quarter of a billion Australian dollars in annual aid flows to the country.

No complex historical process is reducible to a formulaic explanation in terms of one phenomenon. One cannot say the tensions in Solomon 
Islands arose simply from something called "globalization." In its public pronouncements on the issue, the Australian government said nothing about the forestry industry and a great deal about the danger that Solomon Islands could become an outlaw state serving as a haven for terrorists (Kabutaulaka 2005). Yet we cannot fully understand events in Solomon Islands unless we recall the broader economic framework in which they occurred, the corrupting form which foreign investment has taken in that country, and the weakening of an already weak state that resulted.

Similar observations apply to Papua New Guinea (PNG), the largest Melanesian country, and one that is struggling with the challenges of a resource-based export economy in a globalized world. Papua New Guinea has a high degree of dependence on copper, gold, oil, gas, and forestry, with nickel and cobalt soon to be produced from the Ramu project controlled by a Chinese metallurgical company. Work may soon begin on constructing a gas pipeline from the PNG Southern Highlands to Australia. Australia is increasing aid considerably to Papua New Guinea after almost thirty years as the country's major aid donor, from $\mathrm{A} \$ 334$ million in 2003-04 to A $\$ 492$ million in 2005-06. The situation for many Papua New Guineans, especially rural villagers, is worse now than when the country gained independence in I975. Roads are poorer, malaria more widespread, the health system in decline, crime more serious, unemployment levels higher, and HIV/AIDs an emerging threat. Many people in Port Moresby and other urban centers fear for their safety. "The most dramatic decline in PNG," the Australian government concluded in 2004, "has been in the quality of governance. The PNG government currently supports a wide range of programs that are not affordable within current budget parameters. Budget appropriations are often inadequate and agencies rarely receive the funds that have been appropriated. The result is that service delivery is limited and biased toward urban areas. The fundamental weakness of governance undermines investment by government, the private sector and development cooperation partners, threatening both prosperity and stability" (AusAID 2004b, I3).

One way of understanding the poor record of development in Papua New Guinea is to see the country as suffering from a version of the "resource curse," in which a "rentier state" with abundant natural resources lacks accountability to its citizens. As Jonathan DiJohn described the argument: "The main premise of the rentier state model of governance is that when states gain a large proportion of their revenues from external sources, such as resource rents, the reduced necessity of state decision- 
makers to levy domestic taxes causes leaders to be less accountable to individuals and groups within civil society" $(2002,2)$. States that lack a deep taxation relationship with their people have little need to respond to their demands. In the PNG case, politicians certainly feel a need to respond to the demands of voters, but mainly to the small subset of voters in each electorate who happen to belong to the local representative's kin group. Strong but narrow loyalties within society are reproduced at the national level in the political system, with results that do not favor the development of the country as a whole. As with Solomon Islands, we cannot blame all the ills of Papua New Guinea on globalization-the situation, with its roots in culture and history, is too complex for that-yet at the same time we cannot afford to ignore the global economic context in which any PNG government works, in particular its dependence on foreign investors in resource projects for taxation and equity revenue.

Threats to security in the Pacific Islands, then, arise at least in part from globalizing processes of various kinds, and from the way those processes interact with Pacific cultures and political systems. Australia's new engagement in the region, funded by a massive increase in aid to Papua New Guinea and the rest of the Pacific, is a response to those threats and an attempt by Canberra bureaucrats to provide the region with survival equipment for life in a globalized economy. In a broad sense it is a response to globalization. Under Australia's Enhanced Cooperation Program, worth A \$I.I billion over the five years from 2004, Australians are occupying key positions in the public service, and Australian federal police are serving as advisers. Australia is becoming a hands-on supervisor of governance reform in the South Pacific, not only in Solomon Islands and Papua New Guinea, but in Nauru and other states as well. In Canberra the departments of the attorney general, finance, and treasury have established specialized South Pacific units, and the Australian Federal Police, who are playing an increasingly important role in the region, now have an International Deployment Group. AusAID, the Australian aid agency, has staff specializing in "fragile states" and how to make them less fragile.

\section{Conclusion}

One observer has seen "a vocal chorus . . . building within Fiji and the broader Pacific island region that is attributing many of the current economic problems in the region to WTO-sponsored multilateral trade liber- 
alization" and has argued that local policy choices made by Islands governments are what matter in "how the benefits or losses pan out for the country" (Chand 2005, I 24, I 28). The argument that Islands governments should make the right policy choices is undeniable but shallow. In theory, Islands governments should be adapting to the new globalization order and taking the opportunities it offers. Fiji should have reformed sugar years ago. The Solomon Islands government should have stood firm against the logging industry, refused to give remissions on export duties, and invested the returns in village development. Papua New Guinea should have maintained internal security, kept the roads in good order, and built an efficient public service. Pacific Islands economies would work better if landownership were clearly established in law, if there were no disputes over land, and if individuals and groups could use their land assets as collateral to raise capital for investment.

The problem is that these things do not happen, the important issue is why that is the case, and the answers lie less in economic theory than in culture, history, politics, and demography.

For cultural reasons, economic growth of East Asian speed and proportions is unlikely anywhere in the Pacific Islands. Throughout the region, chiefs and elites have enriched themselves handsomely by exploiting old obligations in the cause of new accumulation, but the obligations-to kin, to community, and to chiefs-remain strong. These have not yielded sufficiently to individualism to create the entrepreneurial drive that, according to economic theory, bursts forth in all cultural settings at the first sign of market forces. Itself a culturally bound ideology, neoliberal economics proceeds on the basis of universalist assumptions about psychology and human nature. The key assumption is that individuals are self-maximizing and that market signals are the best way of triggering their self-maximization, which, though private in nature, is said to be in the public interest in the long run. Yet consider the following World Bank analysis of Pacific Islanders' potential for entrepreneurship-in other words, their propensity as individuals to seize market opportunities. Neoliberal assumptions about human nature in a free market setting do not hold generally true, the bank argues, for Pacific Islanders and Pacific Island cultures:

Unlike the Indian Island and Caribbean countries to which they are sometimes compared, Pacific indigenous cultures have remained strong. ... The existence of a defining sense of family, clan, and ethnic identity manifests itself in two 
significant ways. First, social networks defined by clan, and family relations have done much to alleviate the harshest effects of poverty due to access to communally owned land for subsistence agriculture, as well as strong social norms to provide support to the needy in the community. Second, the primacy of the community places social barriers against the development of a culture of aggressive private entrepreneurship, as all successes (and failures) are viewed as belonging to the family or clan. Moreover, these cultural standards mean that there is generally widespread support for the involvement of the public sector in many economic activities that in other countries would be regarded as solely in the sphere of private activity. (World Bank 2005, 2-3)

The cultural story in the Pacific is more complicated than this World Bank characterization suggests. The restructuring of the Fiji sugar industry, for example, is taking place largely in the context of a Fiji-Indian culture that has proven more responsive to entrepreneurial opportunities than its indigenous Fijian counterpart. Many Papua New Guineans have proven to react swiftly to the lure of higher world prices for agricultural commodities. And, because of globalization, Pacific "indigenous cultures" are not static but constantly absorbing and adopting individualist values. The bank's central point, however, remains compelling and instantly recognizable to people in the region: Globalization in the Pacific Islands is interacting with cultures in ways that may not produce positive outcomes. Rather than being predictable, the situation is complex and variable and the outcomes are potentially negative.

Globalization will probably widen inequalities throughout the Pacific, and some countries will benefit more than others. The main reasons for this divergence of effects are the obvious but important ones of culture, history, politics, and demography. On the UN Human Development Index, Papua New Guinea (I37), Solomon Islands (I 28), and Vanuatu (I I 8) rank considerably lower than Fiji (92), Sāmoa (74), or Tonga (54) (HDI 2005). The Human Development Index is a rough guide at best, but it offers an approximate indication of relative levels of development. The outside world reached Papua New Guinea, Solomon Islands, and Vanuatu later than their neighbors and these countries consist of hundreds of different identity groups, often smaller than the language groups that contain them. Thrown together by the experience of colonial rule, they have little else to foster a sense of common national destiny. In Fiji, Sāmoa, Tonga, Tuvalu, and Kiribati, by contrast, the modern nation-state is home to a majority population of Pacific Islanders speaking a single language, possessing a common sense of national identity, and bound together by a 
culture of chieftainship and hierarchy that has adapted more readily to the demands of modern government and the modern economy than have the more egalitarian political cultures to the west (Reilly 2004). At the same time, population growth is faster in Solomon Islands, Vanuatu, and Papua New Guinea than in Fiji, Sāmoa, and Tonga. Where half the population has not reached adulthood, as is the case in Solomon Islands, Vanuatu, and Papua New Guinea, the challenge of increasing gross domestic product per capita is correspondingly greater. The outlook for labor migration also differs from one part of the Pacific to another, this time for historical and political reasons. Labor migration to wealthier countries from Polynesia, Micronesia, and Fiji will continue, even accelerate, as Pacific Islanders take advantage of access created by free association agreements and earlier colonial links. Meanwhile, labor migration from Papua New Guinea, Solomon Islands, and Vanuatu-the countries that need it most—is likely to languish.

The weakness of the state in Melanesia outside Fiji-itself the product of culture and history-goes a long way toward explaining why globalization is not enhancing the development prospects of Papua New Guinea, Solomon Islands, and Vanuatu. Rapacious timber companies played a part in the collapse of law and order in Solomon Islands, and continue to undermine the integrity of its governments. The dominance of resource exploitation in the PNG economy skews the loyalties and obligations of the state toward foreign investors. The regional intervention in Solomon Islands and the Enhanced Cooperation Program in Papua New Guinea are unlikely to succeed in the long term without a fresh focus on villages and more diversified strategies for national economic development. Even the basic promise of globalization-that it will enhance the enmeshment of developing countries with the global economy-may not be fulfilled in weak Melanesian states.

When we ponder the globalizing changes now sweeping over the Pacific Islands region, we should remember that the economic doctrine behind globalization is the product of Western culture and of a particular phase in the history of the global economy. Far from being "truth" in some objective scientific sense, the doctrine enshrines a set of highly political policy recommendations, among them that greater inequality is to be tolerated for the sake of faster economic growth. We should also remember that cultural, historical, and demographic circumstances at the receiving end of globalization in the Island states of the Pacific play determining roles in whether the process has positive or negative consequences. 


\section{Note}

I Mohanty's source was the Fiji Bureau of Statistics, Tourism and Migration Statistics and Statistical News, 1987-2004, and the 2004 figures went to September. Of 91,275 permanent departures from 1987 to 2004, Indo-Fijians accounted for 80,744 .

\section{References}

AusAID

2004a Pacific Regional Aid Strategy, 2004-2009. Canberra: AusAID.

2004 b Australia's International Development Cooperation 2004-05. Canberra: AusAID.

Australian Parliament

2002 Pacific Agreement on Closer Economic Relations (PACER), done at Nauru on I8 August 200I, National Interest Analysis. Documents tabled on I2 March 2002. Treaties Committee, Parliament of the Commonwealth of Australia.

Australian Senate

2003 A Pacific Engaged: Australia's Relations with Papua New Guinea and the Island States of the South-west Pacific. Senate Foreign Affairs, Defence and Trade References Committee, Parliament of the Commonwealth of Australia.

Chand, Satish

2005 Globalization or Self-inflicted Wounds in the Fiji Sugar and Garment Industries. Pacific Economic Bulletin 20 (3): I24-I 28.

DiJohn, Jonathan

2002 Mineral Resource Abundance and Violent Political Conflict: A Critical Assessment of the Rentier State Model. Crisis States Programme, Working Papers Series I. London: London School of Economics.

Dinnen, Sinclair

2002 Winners and Losers: Politics and Disorder in the Solomon Islands, 2000-2002. Journal of Pacific History 37 (3): 285-298.

Downer, Alexander

2004 Australia's Growing Obligations in the Pacific. Commentary, Pacific Islands Report, 29 June. Accessible online at <http://archives.pireport .org/archive/2004/june/06\%2D29\%2Dcom.htm>

EC, European Commission

1996 Green Paper on Relations between the European Union and the ACP Countries on the Eve of the 2 Ist Century: Challenges and Options for a New Partnership. Brussels: European Commission. 


\section{Economist}

2006 The Rich, the Poor and the Growing Gap between Them. The Economist I 5 June: 25-27. Accessible online at <http://www.economist .com/world/displaystory.cfm?story_id=70559I I >

EPG, Eminent Person's Group

2004 The Eminent Persons' Group Review of the Pacific Islands Forum, April 2004. Accessible online at <http://www.pacificplan.org/tiki-download _file.php/?fileId $=4 \mathrm{I}>$

Fraenkel, Jon

2004 The Manipulation of Custom: From Uprising to Intervention in the Solomon Islands. Wellington: Victoria University Press; Canberra: Pandanus Books.

Gillson, Ian, Adrian Hewitt, and Sheila Page

2005 Forthcoming Changes in the EU Banana/Sugar Markets: A Menu of Options for an Effective EU Transitional Package Report. London: Overseas Development Institute.

HDI, Human Development Index

2005 International Cooperation at a Crossroads: Aid, Trade and Security in an Unequal World. Human Development Report 2005. New York: United Nations Development Program.

Held, David

2004 Global Covenant: The Social Democratic Alternative to the Washington Consensus. Cambridge: Polity Press.

Kabutaulaka, Tarcisius Tara

2005 Australian Foreign Policy and the RAMSI Intervention in Solomon Islands. The Contemporary Pacific I7:283-308.

Kelsey, Jane

2004 A People's Guide to PACER: The Implications for the Pacific Islands of the Pacific Agreement on Closer Economic Relations. Suva: Pacific Network on Globalisation.

2005 A People's Guide to the Pacific's Economic Partnership Agreement: Negotiations between the Pacific Islands and the European Union pursuant to the Cotonou Agreement 2000. Suva: World Council of Churches.

Maclellan, Nic

2006 Fiji, the War in Iraq, and the Privatisation of Pacific island Security. Austral Policy Forum 06-I IA, 6 April. Nautilus Institute, RMIT University. Online at <http://nautilus.rmit.edu.au/forum-reports/o6 I Ia -maclellan.html\#n3>

Mohanty, Manoranjan

2005 Globalisation, New Labour Migration and Development in Fiji Islands. 
Paper presented to the Conference on Globalization and Governance Moore, Clive in the Pacific Islands, Australian National University, October.

2004 Happy Isles: The Historical Causes for a Failing State in Solomon Islands, I998-2004. Canberra: Asia Pacific Press.

Narube, Savenaca

2005 Fiji's Economy: Performances and Prospects. Address to the Fiji Australia Business Forum, Nadi, Fiji, I7 October.

PIF, Pacific Islands Forum

2005a Forum Communiqué. Thirty-Sixth Pacific Islands Forum, Papua New Guinea, 25-27 October.

2005b The Pacific Plan for Strengthening Regional Cooperation and Integration. Suva: Pacific Islands Forum Secretariat.

PIR, Pacific Islands Report

2006a Fiji Garment Industry Takes 55 Percent Plunge. Fiji Times Online, 6 April. Accessible online at <http://archives.pireport.org/archive/2006/ april/04-06-09.htm>

2006b Four Fijians Die in Iraq Ambush. Fijilive, 2I April. Accessible online at <http://archives.pireport.org/archive/2006/april/o4\% 2D 2 I \% 2Do7 .htm>

2006c Thousands to Lose Jobs in Fiji Garment Industry. Fiji Times Online, 23 June. Accessible online at <http://pidp.eastwestcenter.org/pireport/ 2006/June/06-23-02.htm>

Reddy, Narendra

2003 Survival Strategies for the Fiji Sugar Industry. Fijian Studies I (2): 265-285.

Reilly, Benjamin

2004 State Functioning and State Failure in the South Pacific. Australian Journal of International Affairs 58 (4): 479-493.

Reserve Bank of Fiji

2005 Quarterly Review. September. Suva: Reserve Bank of Fiji.

Storey, Donovan

2006 Urbanisation in the Pacific. Canberra: State, Society and Governance in Melanesia Project, Australian National University.

White, Michael

2003 The Financial Viability of the Fiji Sugar Corporation: An Assessment from the Corporation's Annual Financial Reports. Fijian Studies I (2):

World Bank $287-300$.

2005 Regional Engagement Framework, FY 2006-2009. Papua New Guinea, Pacific Islands and Timor-Leste Country Unit, East Asia and Pacific Region, Report 3226I-EAP, 3 May. 


\section{Abstract}

Globalization is having its most transformative effects in the Pacific in three areas of economic and political life: trade, labor, and security. The global move from protection to free trade has reached the Pacific and will have its greatest initial impact on Fiji's sugar and garment industries, both of which face major restructuring and possibly extinction. Within ten years, the Pacific Plan might also create economic integration within the entire Pacific Islands Forum area, though the free movement of labor from the Islands into Australia and New Zealand seems unlikely. Thanks in large part to the war in Iraq, Fiji has now joined Sāmoa and Tonga as a remittance economy, but Papua New Guinea, Solomon Islands, and Vanuatu have little access to remittance income. Globalization in Solomon Islands has taken the form of unregulated investment in tropical logging, which has contributed to corrupting the political system. The consequence is regional intervention led by Australia, which is also attempting to shore up Papua New Guinea, where the government's priorities are influenced by its heavy dependence on foreign investors in resource projects. Globalization will probably widen inequalities throughout the Pacific, and some countries will benefit more than others. Cultural, historical, and demographic circumstances at the receiving end of globalization in the Island states of the Pacific play determining roles in whether the process has positive or negative consequences.

KEYWORDS: globalization, trade, labor, security, sugar, garments, logging 